\title{
Three molecular markers suggest different relationships among three Drepanocladus species (Bryophyta: Amblystegiaceae)
}

\author{
Lars Hedenäs ${ }^{1}$ (D)
}

Received: 14 October 2016/Accepted: 8 January 2017/Published online: 7 February 2017

(C) The Author(s) 2017. This article is published with open access at Springerlink.com

\begin{abstract}
Relationships among numerous specimens of Drepanocladus angustifolius (35 specimens), Drepanocladus lycopodioides (71 specimens), and Drepanocladus turgescens (102 specimens) are analysed based on the nuclear internal transcribed spacers 1 and 2 (ITS) and a portion of glyceraldehyde 3-phosphate dehydrogenase $(g p d)$, and the plastid rpl16 G2 intron. Molecular data suggest that neither species is monophyletic as well as significant incongruence among molecular markers. No statistical support for recombination (ITS, $g p d$ ) was found. For some D. lycopodioides and D. turgescens specimens, the molecular information even suggests that they belong to the wrong one of these two species. All such specimens were collected in south Swedish areas where the two species are frequently found growing together and where sporophytes are often common. The occurrence of all such specimens only in these geographical areas is statistically unlikely and suggests that hybridisation occasionally occurs here. While molecular information suggests that the species are not monophyletic, geographical signals could be found for both $D$. angustifolius and D. turgescens.
\end{abstract}

Keywords Geographical signal · Hybrids · Incongruence · Non-monophyletic

Handling editor: Jochen Heinrichs.

Electronic supplementary material The online version of this article (doi:10.1007/s00606-017-1389-8) contains supplementary material, which is available to authorized users.

Lars Hedenäs

lars.hedenas@nrm.se

1 Department of Botany, Swedish Museum of Natural History, Box 50007, 10405 Stockholm, Sweden

\section{Introduction}

Phylogenetic or phylogeographic studies using mitochondrial DNA at low taxonomic levels have shown that c. 1/4 of animal species display species-level paraphyly or polyphyly (Funk and Omland 2003). These authors expected that the percentage should be even higher among plants (cf., Rieseberg and Brouillet 1994). Studies of closely related moss species have repeatedly shown incongruence between molecular partitions or that molecular relationships are incongruent with morphologically circumscribed species (Shaw and Goffinet 2000; Draper et al. 2007, 2015; Natcheva and Cronberg 2007b; Draper and Hedenäs 2009; Hedenäs 2009, 2011, 2015a; Hedenäs et al. 2012; Lewis et al. 2014). Incongruence can therefore be expected relatively often when numerous specimens per species are included in analyses of relationships and can be caused by, for example, insufficient data, rapid diversification, horizontal gene transfer, hybridization, incomplete lineage sorting, convergence caused by natural selection, and variation in evolutionary rates (Wendel and Doyle 1998; Harris 2008). However, evidence additional to results of phylogenetic analyses is often required to decide which explanation is most likely (Wendel and Doyle 1998).

While a widespread occurrence of incongruence among data sets in mosses is well documented, the existence of hybridisation as a potential explanation has often been doubted. However, there exists substantial morphological (Natcheva and Cronberg 2004) as well as molecular (e.g. Natcheva and Cronberg 2007b; Harris 2008; Wyatt et al. 2013) evidence for interspecific hybridisation in mosses, and hybridisation should thus be seriously considered among explanations for the widespread incongruence. Most species involved in morphologically identified hybrids are acrocarpous, short-lived species (colonists, 
annual or short-lived shuttles; sensu During 1979, 2000). Less than $20 \%$ of the species are long-lived shuttles or perennial, and only three (5\%) of the 63 moss hybrids reported were between pleurocarpous species (Natcheva and Cronberg 2004). Are the few known morphologically identified pleurocarpous hybrids indicative of a true low incidence of hybridisation in this moss lineage? The pleurocarpous mosses include around $40 \%$ of moss species diversity, and a much higher number of hybrids would be expected if these are equally common across the moss system. Maybe it is their predominant life strategies rather than the pleurocarpous organisation itself that determines how often morphological hybrids are revealed in nature, since also among acrocarpous species with similar life strategies as pleurocarpous mosses hybrids are rare (Natcheva and Cronberg 2004). A few specimens included in studies of the pleurocarpous Calliergonaceae genera Loeskypnum, Sarmentypnum, Straminergon, and Warnstorfia (Hedenäs 2011, 2015a) had ITS or plastid markers that suggested a different relationship than their morphology. Since plastids are maternally inherited in bryophytes (Natcheva and Cronberg 2007a) and morphologically distinguishable hybrids are known between Sarmentypnum exannulatum (Schimp.) Hedenäs and $S$. trichophyllum (Warnst.) Hedenäs (Sonesson 1966), one possibility is that hybridization could explain some incongruent patterns in this group (Hedenäs 2011, 2015a).

Recent detailed studies of intraspecific molecular variation in the wetland moss Drepanocladus lycopodioides (Brid.) Warnst., using D. aduncus (Hedw.) Warnst. and Drepanocladus turgescens (T.Jensen) Broth. as outgroup, revealed that $D$. turgescens could not always be molecularly distinguished from $D$. lycopodioides (Hedenäs and Bisang 2015: Supplementary Online Fig. 2). Here, this $D$. lycopodioides sequence data set is combined with that of D. turgescens from Hedenäs (2014) and newly generated sequences of the closely related Drepanocladus angustifolius (Hedenäs) (Hedenäs and Rosborg 2009). Together, this provides an excellent data set to study potential incongruence among data sets and to search for evidence of potential hybridisation in a group of pleurocarpous mosses that is not closely related to the earlier studied Calliergonaceae (cf., Huttunen et al. 2012). Drepanocladus angustifolius, D. lycopodioides, and D. turgesecens are rarely difficult to distinguish from each other by morphology and are therefore also suitable to investigate whether molecular relationships are congruent with the morphologically defined species. The null hypothesis to be tested is that the three morphologically defined species correspond with independently evolving molecular lineages. If molecular and morphological incongruence occurs, could this possibly be explained by hybridisation?

\section{Materials and methods}

\section{Plant material}

The morphology of the study species was already described in detail (Hedenäs 1992, 2003), and only the most salient features are mentioned here. The three pleurocarpous mosses are medium-sized to large, green to yellowish, and have spots with a golden gloss when dry. The large alar groups are indistinctly delimited and consist of numerous, mostly incrassate cells. Drepanocladus turgescens has straight, strongly concave leaves that narrow suddenly to an apiculus, whereas the other two species have falcate, less strongly concave leaves that are more or less longly acuminate. Drepanocladus angustifolius has relatively narrow leaves with finely denticulate margins and occasional dorsally prorate cells in the distal lamina, whereas $D$. lycopodioides has very broad leaves with entire or almost entire margins and smooth lamina cells. Drepanocladus angustifolius is known from scattered localities in northern Europe, northern Asia, and North America, D. lycopodioides is restricted to western Eurasia, and D. turgescens occurs in northern to central Europe, northern and central Asia, and North and South America. All three species grow in shallow, more or less calcareous wetlands. In lowland localities, they are mostly found in depressions in rock or soil, in situations that in most years are wet during autumnwinter-spring and periodically dry during summer. In mountain regions, D. angustifolius and D. turgescens in addition occur in late snow-beds that dry out relatively early, or on rocks that are periodically wet from trickling water.

Sequences of 35 specimens of D. angustifolius were newly generated, whereas 71 of D. lycopodioides and 102 of D. turgescens were available from earlier phylogeographic studies (Hedenäs 2014; Hedenäs and Bisang 2015). Because northern Europe was the focus of the earlier studies, this area is well covered, but other portions of Europe or (D. angustifolius, D. turgescens) outside Europe are also represented. Based on the results of Hedenäs and Rosborg (2009), two specimens of D. aduncus were used as outgroup in the analysis. The specimens of $D$. angustifolius are listed in Table 1, whereas those of the other species are listed in Hedenäs (2014) and Hedenäs and Bisang (2015).

\section{Molecular methods}

The molecular methods used here for D. angustifolius were described earlier (Hedenäs 2014; Hedenäs and Bisang 2015), and the reader is referred to these works for further details. For the internal transcribed spacers 1 and 2 (ITS), the primers'18SF' and '26SR' (Rydin et al. 2004) or 'ITS4- 
Table 1 Specimen data and European Nucleotide Archive (EMBL-ENA) accession numbers for the 35 newly generated Drepanocladus angustifolius sequences (sequence data available at: http://www.ebi.ac.uk/ena/data/view/LT627410-LT627514)

PT1131: Sweden. Härjedalen, Linsell; 2007, LH et al.; B121457; LT627410, LT627445, LT627480. PT1132: Sweden. Härjedalen, Storsjö; 2002, LH; B72100; LT627411, LT627446, LT627481. PT1133: Sweden. Härjedalen, Storsjö; 2002, LH; B72101; LT627412, LT627447, LT627482. PT1134: Sweden. Jämtland, Frostviken; 1997, LH and A. Kooijman; B1040; LT627413, LT627448, LT627483. PT1135: Sweden. Jämtland, Frostviken; 1997, LH and A. Kooijman; B1415; LT627414, LT627475, LT627484. PT1136: Sweden. Jämtland, Frostviken; 2003, LH and C. Rosborg; B81958; LT627415, LT627449, LT627485. PT1138: Sweden. Jämtland, Frostviken; 2003, LH and C. Rosborg; B81962; LT627416, LT627450, LT627486. PT1139: Sweden. Jämtland, Frostviken; 1989, LH; B103961; LT627417, LT627451, LT627487. PT1140: Sweden. Jämtland, Frostviken; 2009, LH; B163253; LT627418, LT627452, LT627488. PT1141: Sweden. Jämtland, Frostviken; 2009, LH; B165515; LT627419, LT627453, LT627489. PT1142: Sweden. Jämtland, Åre; 2013, LH; B198958; LT627420, LT627454, LT627490. PT1143: Sweden. Lycksele Lappmark, Tärna; 2012, LH et al.; B195264; LT627421, LT627455, LT627491. PT1144: Sweden. Lycksele Lappmark, Tärna; 2012, LH et al.; B195226; LT627422, LT627456, LT627492. PT1145: Sweden. Lycksele Lappmark, Tärna; 2012, LH et al.; B195231; LT627423, LT627457, LT627493. PT1146: Sweden. Pite Lappmark, Arjeplog; 2006, LH et al.; B114341; LT627424, LT627458, LT627494. PT1147: Sweden. Torne Lappmark, Jukkasjärvi; 1992, LH; B104115; LT627425, LT627459, LT627495. PT1148: Sweden. Torne Lappmark, Karesuando; 2011, T. Hallingbäck 5562; B188878; LT627426, LT627460, LT627496. PT1149: Norway. Nordland, Saltdal; 2013, LH; B197298; LT627427, LT627461, LT627497. PT1150: Norway. Nordland, Saltdal; 2013, LH; B197299; LT627428, LT627462, LT627498. PT1151: Norway. Nord-Trøndelag, Røyrvik; 2014, LH; B204965; LT627429, LT627463, LT627499. PT1152: Norway. Nord-Trøndelag, Røyrvik; 2014, LH; B205289; LT627430, LT627464, LT627500. PT1153: Norway. Nord-Trøndelag, Røyrvik; 2014, LH; B205329; LT627431, LT627465, LT627501. PT1154: Norway. Nord-Trøndelag, Røyrvik; 2014, LH; B205332; LT627432, LT627466, LT627502. PT1155: Norway. Troms, Bardu; 2008, LH; B138456; LT627433, LT627467, LT627503. PT1156: Norway. Troms, Lyngen; 2003, LH; B81874; LT627434, LT627468, LT627504. PT1157: Finland. Kittilän Lappi. Kittilä; 1993, T. Ulvinen; B105690; LT627435, LT627476, LT627505. PT1158: Iceland. N-Iceland, Hólmatungur; 1976, B. Jóhannsson; B104359; LT627436, LT627469, LT627506. PT1159: Canada. NW Territories, Aklavik; 1963, Krajina et al. 63070724; B105730; LT627437, LT627470, LT627507. PT1160: Canada. Yukon Territories. Mt. Klotz; 1973, D.H. Vitt 7662; B105744; LT627438, LT627477, LT627508. PT1161: Greenland. S-Disko, Blaesedalen; 2004, R. Ejrnaes; B99329; LT627439, LT627471, LT627509. PT1162: United States. Alaska, Richardson Hwy; 1997, C. Schröck 13969; B157476; LT627440, LT627478, LT627510. PT1163: United States. California, Inyo Co.; 2002, E. Laeger 1454; B78056; LT627441, LT627479, LT627511. PT1164: United States. California, N Sier Nevada; 2000, J.R. Shevock and B. Ertter 19884; B192047; LT627442, LT627472, LT627512. PT1165: United States. Wyoming, Albany Co.; 2007, Y.I. Kosovich-Anderson 1621; B132933; LT627443, LT627473, LT627513. PT1166: United States. Wyoming, Albany Co.; 2007, Y.I. Kosovich-Anderson 1635; B132934; LT627444, LT627474, LT627514

Data format: Sample No.: Locality; Coll. Year, Collector \{collector's No.\} ( $L H=$ L.Hedenäs); S registration No.; EMBL-ENA accession numbers for ITS, gpd, rpl16

bryo' (Stech 1999) and 'ITSbryoR' (Hedenäs 2014) were used. For a portion of glyceraldehyde 3-phosphate dehydrogenase $(g p d)$, the primers '1790F' (Wall 2002), 'GPD68F', 'GPD-460F' (Hedenäs and Bisang 2015), 'GPD3050Rr' (Hedenäs 2014), and 'GPD-bryonestedR' (Hedenäs and Bisang 2013) were employed, and for the rpl16 G2 intron (rpl16), the primers 'F71' (Jordan et al. 1996) and 'rpl16-antR2' (Hedenäs 2008) were used.

Paralogous ITS haplotypes are rarely encountered in bryophytes (but see Košnar et al. 2012). The ITS chromatograms generated in this study did not show 'messy' patterns or noise that could suggest paralogy, and the 5.8S gene was invariable among all samples (cf., Shaw et al. 2002; Feliner and Rosselló 2007). The revealed ITS variation is therefore interpreted as not being a result of paralogy.

\section{Sequence editing and alignment}

The newly generated nucleotide sequence fragments were edited and assembled for each DNA region using PhyDE ${ }^{\circledR}$ 0.9971 (http://www.phyde.de/index.html; accessed 21 April 2016). The new and earlier assembled sequences were manually aligned in $\mathrm{PhyDE}^{\circledR}$ 0.9971. Regions of partially incomplete data in the beginning and end of the sequences were identified and excluded from subsequent analyses. The few gaps present were coded as present or absent. They provided additional evidence to distinguish haplotypes and were therefore included in the analyses. The sequence alignments used in the analyses are found in Online Resources 1-3. European Nucleotide Archive (EMBL-ENA) accession numbers for $D$. angustifolius specimens are listed in Table 1, and GenBank accession numbers for the other two species are found in Hedenäs (2014) and Hedenäs and Bisang (2015), respectively.

\section{Molecular analyses}

A preliminary analysis was made with the program TCS to evaluate relationships among haplotypes (Clement et al. 2000) and to confirm the presence of reticulation that was revealed in the earlier studies (Hedenäs 2014; Hedenäs and Bisang 2015; results not shown). Reticulation was confirmed, and NeighborNet (NN) split networks were therefore generated using SplitsTree 4.12.6 (Huson and Bryant 2006). Jacknife analyses (1000 replications) were performed with the program TNT (Goloboff et al. 2003) to test whether there exist supported lineages. The three data 
partitions were first analysed separately, since the ILD test (Farris et al. 1995; 200 replicates) indicated that the molecular data sets are incongruent (ITS vs. gpd: $p=0.005$; ITS vs. rpl16: $p=0.015$; gpd vs. rpl16: $p=0.010)$. However, since no contradictions were found among well-supported branches in the Jacknife trees, the data sets were in addition concatenated and analysed jointly. Finally, the statistical support for potential recombination in the nuclear markers was tested by the $\Phi_{w}$ statistic (Bruen et al. 2006) as implemented in SplitsTree4 (Huson and Bryant 2006).

\section{Results}

After regions at the beginnings and ends of the alignments that were incomplete for some specimens had been deleted, the total number of aligned ITS sites in the 210 studied Drepanocladus specimens, including the two outgroup $D$. aduncus ones, was 708, including 16 base substitutions (10 informative) and 4 indels (1). For gpd, the corresponding value was 668, with 62 base substitutions (32) and 2 indels (2), and for $r p l 16$, the value was 671, including 7 base substitutions (4) and 3 indels (3). The sequence lengths were: D. angustifolius (ITS: 703-707; gpd: 665-666; rpl16: 668-670; $n=35) ;$ D. lycopodioides (703; 665; 667-669; $n=71) ;$ D. turgescens (703; 665; 666-669; $n=102)$; and for the outgroup, D. aduncus $(703 ; 667 ; 670$; $n=2)$.

The Jacknife tree based on the concatenated data is poorly resolved (Fig. 1a). In a NN split network based on the same data, two North American specimens of morphologically D. angustifolius (A1 in Fig. 1b) deviate strongly from the rest of the ingroup. Drepanocladus lycopodioides is found in two separate lineages without (L1-L3) or with (L4-L5) moderate (83) Jacknife support (Fig. 1b). The D. lycopodioides L1-L3 branch in the split network includes three morphologically D. turgescens specimens from Gotland (P07) and Öland (PT1002, PT1019) in Baltic Sweden. Most of the D. angustifolius specimens are found in the two lineages A3 and A4 with moderate (80) or weak (67) Jacknife support. A3 includes mainly European specimens plus PT1160 (Yukon) and PT1161 (Greenland) and A4 only North American representatives (Fig. 1b). In addition, two European specimens (A2) are found in between A3 and A4. Drepanocladus turgescens specimens are found in a 'central' position among the three study species, with some geographical structure (Fig. 1b). Arctic and most northern Scandinavian specimens are found in haplotypes to the right of several central splits in the network portions encompassing $D$. turgescens. To the left of these splits, European specimens from $\mathrm{S}$ of Scandinavia are found in the upper portion and
extra-European specimens in the lower portion, in both cases mixed with Scandinavian specimens.

The NN split networks based on the three individual markers (Fig. 2) show the contributions of the respective markers to the network based on the concatenated data. ITS data (Fig. 2a) contribute most to the split of most $D$. angustifolius specimens into groups A3 and A4 in the network based on the concatenated data (Fig. 1b), and also to the weakly supported Svalbard D. turgescens group T2 (Fig. 1b) with specimens PT1104 and PT1106. Five positions in gpd suggest that D. lycopodioides specimens belong to two separate lineages (Fig. 2b). In one of the five positions (not shown), the samples of one group are mainly similar to $D$. angustifolius and in the other ones to $D$. turgescens. Two or three markers place the N Scandinavian and Icelandic D. angustifolius specimens PT1158 (3 markers; Iceland) and PT1131 (2; Härjedalen) separate from other members of the species. The two Californian $D$. angustifolius specimens PT1163 (3) and PT1164 (2) appeared even more separated from other specimens (Fig. 2). Since their morphology suggests D. angustifolius, the sequences for these two sequences were blasted (BLAST; http://blast.ncbi.nlm.nih.gov/Blast.cgi; accessed 30 August 2016), and this resulted in closest similarities with Drepanocladus sendtneri (Schimp. ex H.Müll.) Warnst. and D. sordidus (Müll.Hal.) Hedenäs for ITS, D. aduncus (PT1163) or D. turgescens (PT1164) for gpd, and D. turgescens (PT1163) or D. aduncus (PT1164) for rpl16. It should be noted that no gpd sequences for $D$. sendtneri or D. sordidus exist in GenBank. In the ITS network, one specimen of morphologically D. lycopodioides from Gotland, Baltic Sweden (PT190) is found in the lower portion of a D. turgescens branch (Fig. 2a), the three specimens of morphologically $D$. turgescens that were found among $D$. lycopodioides in the concatenated data set are also found at such a position in the gpd network (Fig. 2b), and in the rpl16 network, the just mentioned D. lycopodioides PT190 is again found among $D$. turgescens, and one specimen of morphologically $D$. turgescens from Västergötland, S Sweden (PT1088) is found among D. lycopodioides (Fig. 2c).

No statistical support for recombination was found $\left(\Phi_{w}\right.$ statistic: ITS, $p=1$; gpd, $p=0.6787$; Total nuclear data: $p=0.0854)$.

\section{Discussion}

Neither the individual markers nor the concatenated molecular data set suggest that the three morphologically defined species correspond with three independently evolving lineages. The different molecular partitions and morphology provide partly different signals. This is neither 

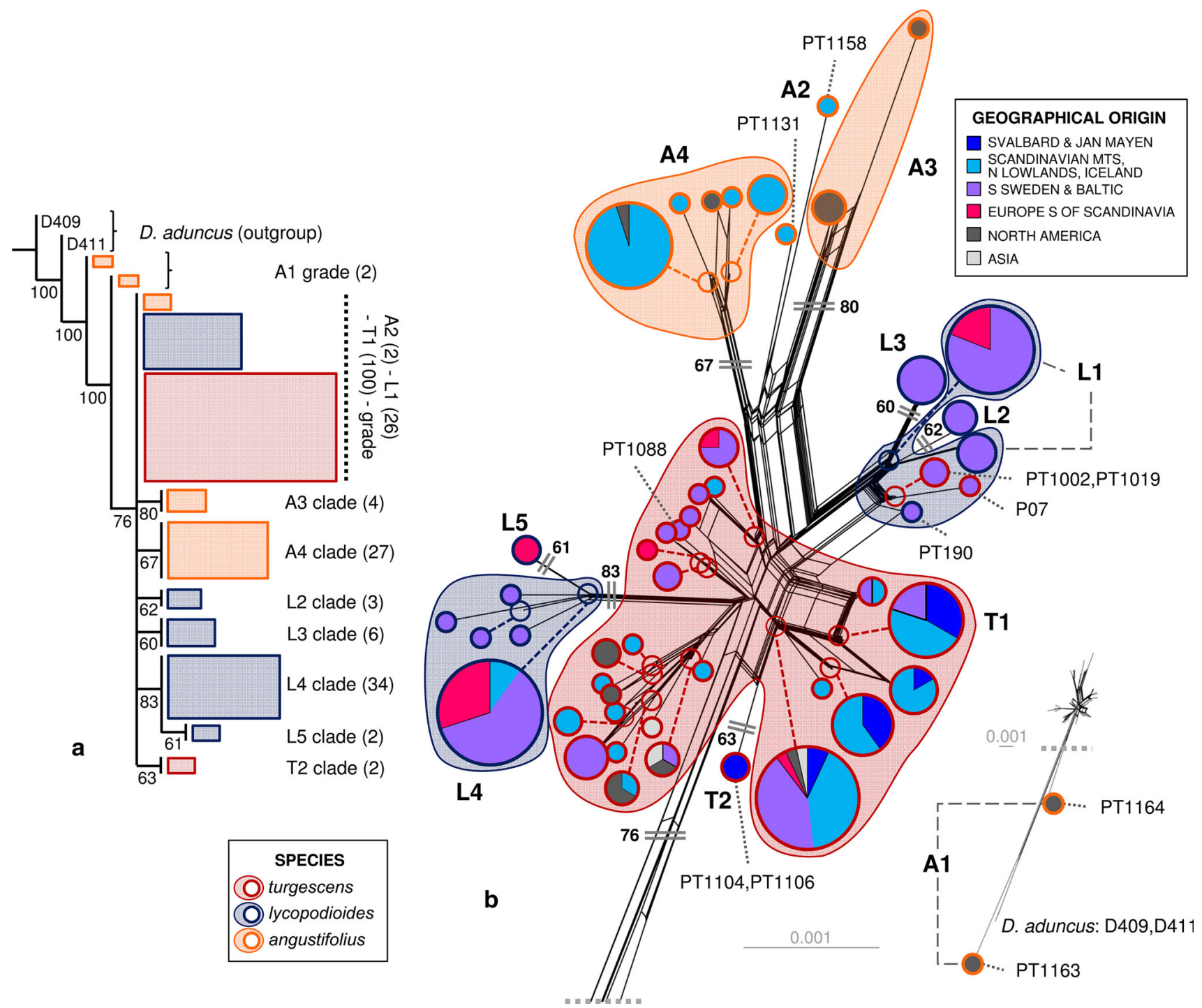

Fig. 1 Relationships among Drepanocladus angustifolius, D. lycopodioides, and $D$. turgescens, based on the total molecular data set (ITS, gpd, rpl16), using D. aduncus as outgroup. a Jacknife tree (1000 replications) showing branches with a support of 60 or more, indicated under the branches. Numbers after clade or grade names indicate numbers of specimens that belong to the respective clade or grade and box sizes are proportional to the number of specimens.

evident from the Jacknife tree based on concatenated data (Fig. 1a) nor from Jacknife trees based on individual markers (not shown), where no clear relationships among the species or specimens are seen. This is not surprising since a tree, a special case of network (Morrison 2014,2016 ), is unlikely to correctly display relationships in cases like the present where relationships are clearly not tree-like. The split networks indicate significant variation among specimens within morphologically defined species and also display relationships among species that are more complicated than suggested by the earlier exemplar-based molecular study which included the three species (Hedenäs b NeigborNet split network. Branches with $\geq 60$ Jacknife support are indicated by double lines and support value. Individual samples ( $\mathrm{P}$ or PT numbers) indicated appear at different positions in the split networks based on individual markers, see Fig. 2. The species (a, b) and geographical origins (b) of the samples are indicated by different colours, and grades or clades $(\mathbf{a}, \mathbf{b})$ with combinations of letters and numbers (e.g. A1-A4 for D. angustifolius)

and Rosborg 2009). Unfortunately, since there is currently no analytical framework for computing rooted evolutionary networks of reasonable sizes (Morrison 2016), it is not possible to formally test whether the species are monophyletic or not in a network context.

The exemplar-based phylogeny of Drepanocladus suggests that the three study species form a monophyletic group (Hedenäs and Rosborg 2009), and the present study cannot refute this. Under the present scenario, D. lycopodioides and most of $D$. angustifolius likely evolved from ancestors among a paraphyletic D. turgescens (Fig. 1b). Intuitively one would expect that the species deviating 

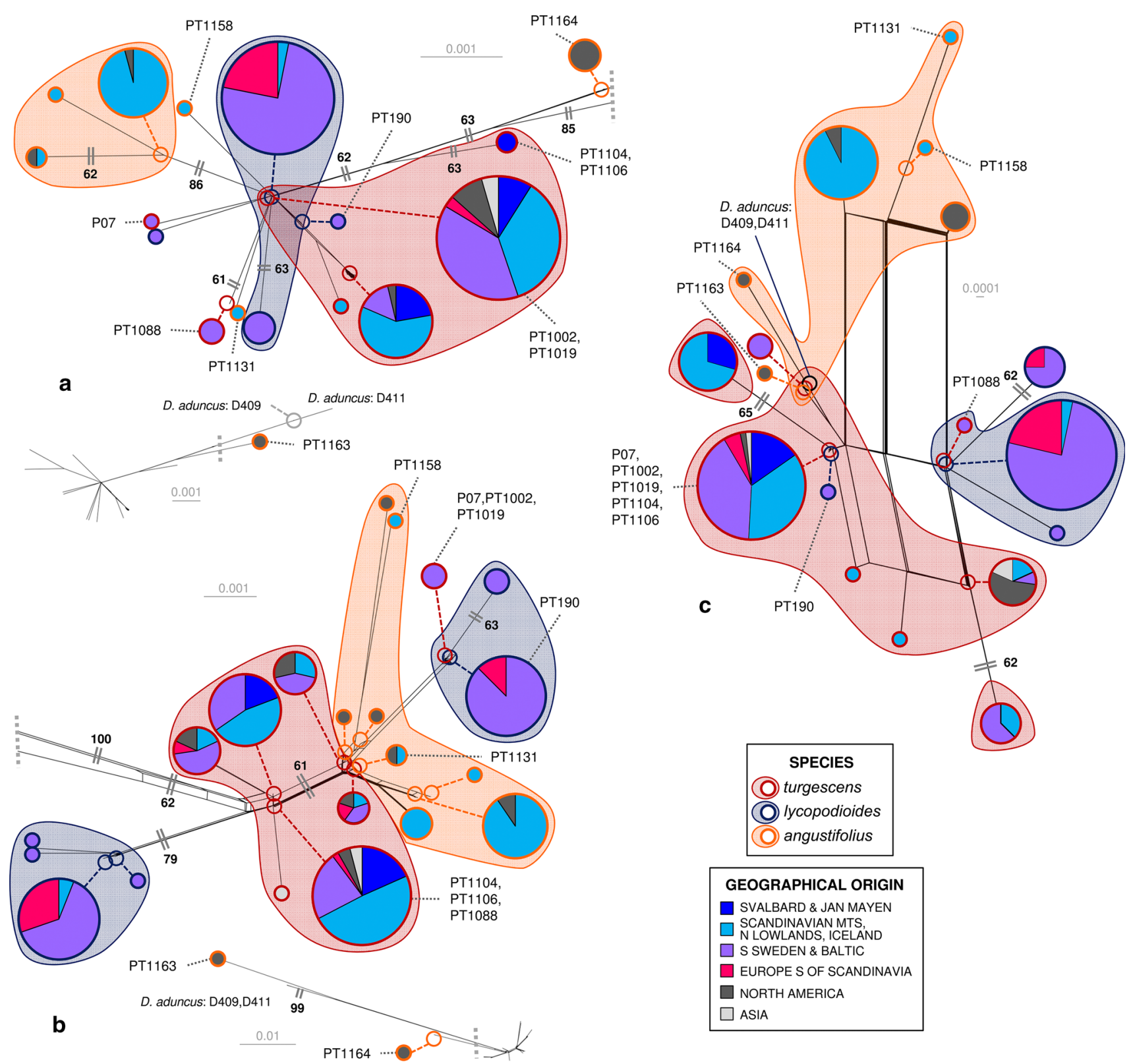

Fig. 2 NeigborNet split network relationships among Drepanocladus angustifolius, D. lycopodioides, and D. turgescens, based on the nuclear a ITS and $\mathbf{b}$ gpd, and on the plastid $\mathbf{c}$ rpl16, using D. aduncus as outgroup. Branches with $\geq 60$ Jacknife support in a Jacknife

most strongly in morphology from other members of the genus, D. turgescens (Hedenäs and Rosborg 2009), should have evolved from one of the other two species studied or that they all evolved from the same ancestor. However, it seems like in this case the more commonly occurring leaf shape in Drepanocladus, with gradually narrowed and acuminate leaves, may have re-evolved from the ovate or broadly ovate and upwards suddenly narrowed leaves with a short apiculus that are found in D. turgescens. analysis are indicated by double lines and support value. Individual samples with $\mathrm{P}$ or PT numbers appear at different positions in the different analyses. The species and geographical origins of the samples are indicated by different colours

The present results are in line with those of Funk and Omland (2003), who showed that in animals, species paraphyly is a common phenomenon. Besides the present results, there are now numerous bryophyte studies that suggest the occurrence of either species paraphyly, incongruence among different molecular data sets, or between molecular and morphological information within genera or among closely related genera (e.g. Shaw 2000; Shaw and Goffinet 2000; Shaw et al. 2005; Natcheva and Cronberg 
2007a, b; Harris 2008; Draper and Hedenäs 2009; Hedenäs 2009, 2011, 2012a, 2015a; Kreier et al. 2010; Vanderpoorten et al. 2010; Hedenäs et al. 2012; Lewis et al. 2014). Deviations from a tree-like evolution with species evolving in a bifurcating process are therefore not to be considered strange, but are actually often encountered also among bryophytes.

As mentioned in the introduction, it is difficult to pinpoint the mechanisms behind incongruence of the kind found here without additional, independent information (Wendel and Doyle 1998). Different processes may contribute to varying degrees towards producing a specific observed pattern and the actual causes are therefore difficult to disentangle. In the present study, no statistical support for recombination is present for individual or concatenated nuclear markers. This could suggest that incomplete lineage sorting explains most of the lack of congruence between the morphological species and the different molecular partitions. However, at the same time circumstantial evidence suggests that hybridisation or other mechanisms of transfer of genetic material is at least part of the reason for the unexpected and striking positions of a few specimens in the NN split networks. Transfer of genetic material should be most likely in situations where species grow intimately together. In Scandinavia, this situation is found especially in the Baltic limestone areas for D. lycopodioides and D. turgescens, both of which are frequent and often occur together. Also in Västergötland in $\mathrm{S}$ Sweden, both these species occur in a restricted area (Österplana), and joint occurrences in Västergötland were likely more widespread earlier. Drepanocladus turgescens occurred well outside its extant localities after the last glacial period (cf., Wastegård et al. 1996), and $D$. lycopodioides was more common before modern agriculture was established in the second half of the 20th Century (the species is now absent on several earlier localities; Hedenäs, personal observation). Drepanocladus angustifolius and D. turgescens can occasionally be found together in some mountain regions, and D. angustifolius and $D$. lycopodioides can occur together in some boreal lowland regions in northern Finland. However, in none of these cases the species are both as frequent and as frequently growing close to each other or intermixed as D. lycopodioides and D. turgescens in Öland, Gotland, and to some degree Västergötland. Öland and Gotland are also the regions where sporophytes are currently frequent in both species in some years, and conditions for the formation also of hybrid sporophytes are thus likely present. All five specimens with molecular identities that deviated from morphology were collected in Öland, Gotland, or Västergötland, even if only $61(29.3 \%)$ of the 208 analysed samples were from here. This is an unlikely distribution by chance (Fischer exact $p=0.0019$ ) and suggests that the processes behind are regional rather than species-wide. Thus, incomplete lineage sorting does not seem to be a likely explanation here unless this random process displays regional variation.

Hybrid sporophytes are formed occasionally in some moss species that occur within the Scandinavian distribution areas of the three study species, for example, Sarmentypnum trichophyllum and S. exannulatum (Sonesson 1966), and Tortella rigens Alberts. and T. tortuosa (Hedw.) Limpr. or T. inclinata (R.Hedw.) Limpr. (Hedenäs 2015b), and examples of hybrid sporophytes or putative gametophytic hybrids are otherwise abundant (Natcheva and Cronberg 2004). Since geographical circumstances suggest that hybridization may occur between $D$. lycopodioides and D. turgescens, it would therefore be highly interesting to grow spores to adult plants as Sonesson (1966) did or to explore the molecular variation among spores of $D$. lycopodioides and D. turgescens from sites in Öland or Gotland where both species grow intermixed and sporophytes are sometimes produced. In such a case, a combination of information from nuclear and plastid markers is useful to find potential hybrids. In other approaches, studies of more variable markers, such as microsatellites or isoenzymes, could be helpful to reveal potential cases of hybridisation (e.g. Cronberg and Natcheva 2002). If hybridisation explains the 'incorrect' placements of $D$. turgescens PT1088 and D. lycopodioides PT190 in the plastid network, then the maternal parent must have been D. lycopodioides in the first case, and D. turgescens in the second since, as far as we know, chloroplasts are maternally inherited in bryophytes (Duckett et al. 1983; McDaniel et al. 2007; Natcheva and Cronberg 2007a). Besides hybridisation and introgression, horizontal chloroplast transfer has been shown to occur (Cristina Acosta and Premoli 2010; Stegemann et al. 2012), although this has not yet been shown to occur in bryophytes.

The molecular data provide a geographical signal within $D$. turgescens and D. angustifolius that is evident in the split network based on the concatenated data (Fig. 1b). Such a geographical signal is absent in the western Eurasiatic endemic D. lycopodioides. In D. turgescens, the relationships among $\mathrm{N}$ European specimens unsurprisingly reflect the geographical differentiation found by Hedenäs (2014). In addition, almost all extra-European samples are found, mixed with some European specimens, in a lineage in the lower left of D. turgescens in Fig. 1b. Whereas one major lineage of $D$. angustifolius (A3) includes only North American specimens, the other (A4) includes almost exclusively European specimens and in addition two specimens from Yukon and Greenland, respectively. Since ITS places the two specimens PT1163 and PT1164 with $D$. sendtneri or D. sordidus, and most other North American specimens of D. angustifolius are found with PT1164 
(Fig. 2a), this marker suggests that most North American $D$. angustifolius are related to D. sendtneri or D. sordidus rather than to European D. angustifolius. The two specimens PT1163 and PT1164 (from California) are molecularly clearly different from other specimens of the ingroup also in one of the two other studied markers. Molecular differences between North American and European moss populations within a species are well known (e.g. Shaw et al. 2008; Hedenäs 2012a, b) and suggest that the relationships among North American specimens, and between these and European ones deserve further study for both $D$. angustifolius and D. turgescens.

Acknowledgements I thank Bodil Cronholm and Annika Bengtson for their efficient laboratory work, and two reviewers for constructive comments.

\section{Compliance with ethical standards}

Conflict of interest The author declares that he has no conflict of interest.

Open Access This article is distributed under the terms of the Creative Commons Attribution 4.0 International License (http://crea tivecommons.org/licenses/by/4.0/), which permits unrestricted use, distribution, and reproduction in any medium, provided you give appropriate credit to the original author(s) and the source, provide a link to the Creative Commons license, and indicate if changes were made.

\section{Information on Electronic Supplementary Material}

Online Resource 1. Alignment of ITS sequences in nexus format. The last four positions with data, separated from the rest by an empty position, constitute the indel coding.

Online Resource 2. Alignment of gpd sequences in nexus format. The last two positions with data, separated from the rest by an empty position, constitute the indel coding.

Online Resource 3. Alignment of $r p l 16$ sequences in nexus format. The last three positions with data, separated from the rest by an empty position, constitute the indel coding.

\section{References}

Bruen TC, Hervé P, Bryant D (2006) A simple and robust statistical test for detecting the presence of recombination. Genetics 172:2665-2681. doi:10.1534/genetics.105.048975

Clement M, Posada D, Crandall KA (2000) TCS: a computer program to estimate gene genealogies. Molec Ecol 9:1657-1659. doi:10. 1046/j.1365-294x.2000.01020.x

Cristina Acosta M, Premoli AC (2010) Evidence of chloroplast capture in South American Nothofagus (subgenus Nothofagus, Nothofagaceae). Molec Phylogen Evol 54:235-242. doi:10. 1016/j.ympev.2009.08.008

Cronberg N, Natcheva R (2002) Hybridization between the peat mosses, Sphagnum capillifolium and S. quinquefarium (Sphagnaceae, Bryophyta) as inferred by morphological characters and isozyme markers. Pl Syst Evol 234:53-70. doi:10.1007/s00606002-0196-y

Draper I, Hedenäs L (2009) Circumscription of European taxa within the Sciuro-hypnum reflexum complex (Brachytheciaceae, Bryophyta), based on molecular and morphological data. Taxon 58:572-584

Draper I, Hedenäs L, Grimm GW (2007) Molecular and morphological incongruence in European species of Isothecium (Bryophyta). Molec Phylogen Evol 42:700-716. doi:10.1016/j.ympev. 2006.09.021

Draper I, Hedenäs L, Stech M, Patiño J, Werner O, GonzálezMancebo JM, Sim-Sim M, Lopes T, Ros RM (2015) How many species of Isothecium (Lembophyllaceae, Bryophyta) are there in Macaronesia? A survey using integrative taxonomy. Bot J Linn Soc 177:418-438. doi:10.1111/boj.12250

Duckett JG, Carothers ZB, Miller CCJ (1983) Gametogenesis. In: Schuster RM (ed) New manual of bryology, vol 1. The Hattori Botanical Laboratory, Nichinan, pp 232-275

During HJ (1979) Life strategies of bryophytes, a preliminary review. Lindbergia 5:2-18

During HJ (2000) Life history characteristics of threatened bryophytes. J Nat Conservation 9:19-26

Farris JS, Källersjö M, Kluge AG, Bult C (1995) Testing significance of incongruence. Cladistics 10:315-319. doi:10.1111/j.10960031.1994.tb00181.x

Feliner GN, Rosselló JA (2007) Better the devil you know? Guidelines for insightful utilization of nrDNA ITS in specieslevel evolutionary studies in plants. Molec Phylogen Evol 44:911-919. doi:10.1016/j.ympev.2007.01.013

Funk DJ, Omland KE (2003) Species-level paraphyly and polyphyly: frequency, causes, and consequences, with insights from animal mitochondrial DNA. Annual Rev Ecol Evol Syst 34:397-423. doi:10.1146/annurev.ecolsys.34.011802.132421

Goloboff P, Farris J, Nixon K (2003) Tree analysis using new technology. Available at: www.zmuc.dk/public/phylogeny. Accessed 5 Mar 2014

Harris ESJ (2008) Paraphyly and multiple causes of phylogenetic incongruence in the moss genus Plagiomnium (Mniaceae). Taxon 57:417-433

Hedenäs L (1992) The genus Pseudocalliergon in northern Europe. Lindbergia 16:80-99

Hedenäs L (2003) The European species of the Calliergon-Scorpidium-Drepanocladus complex, including some related or similar species. Meylania 28:1-116

Hedenäs L (2008) Molecular variation and speciation in Antitrichia curtipendula s. 1. (Leucodontaceae, Bryophyta). Bot J Linn Soc 156:341-354. doi:10.1111/j.1095-8339.2007.00775.x

Hedenäs L (2009) Relationships among Arctic and non-Arctic haplotypes of the moss species Scorpidium cossonii and Scorpidium scorpioides (Calliergonaceae). Pl Syst Evol 277:217-231. doi:10.1007/s00606-008-0131-y

Hedenäs L (2011) Incongruence among morphological species circumscriptions and two molecular data sets in Sarmentypnum (Bryophyta: Calliergonaceae). Taxon 60:1596-1606

Hedenäs L (2012a) Global phylogeography in Sanionia uncinata (Amblystegiaceae, Bryophyta). Bot J Linn Soc 168:19-42. doi:10.1111/j.1095-8339.2011.01189.x

Hedenäs L (2012b) Molecular differentiation within European Cratoneuron filicinum, and differences towards Asiatic and American populations. Pl Syst Evol 298:937-945. doi:10.1007/ s00606-012-0603-y

Hedenäs L (2014) Intraspecific genetic variation in selected mosses of Scandinavian interglacial refugia suggests contrasting distribution history patterns. Bot J Linn Soc 176:295-310. doi:10.1111/ boj. 12210 
Hedenäs L (2015a) Molecular and morphological incongruence among the genera around Sarmentypnum (Bryophyta: Calliergonaceae). Nova Hedwigia 100:279-292. doi:10.1127/nova hedwigia/2014/0226

Hedenäs L (2015b) Tortella rigens (Bryophyta, Pottiaceae): relationships, regional variation, and conservation aspects. Pl Syst Evol 301:1361-1375. doi:10.1007/s00606-014-1159-9

Hedenäs L, Bisang I (2013) Do male and female plants display different haplotype patterns in the moss Drepanocladus trifarius (Bryophyta, Amblystegiaceae)? Polish Bot J 58:279-285. doi:10. 2478/pbj-2013-0028

Hedenäs L, Bisang I (2015) Infraspecific diversity in a sporedispersed species with limited distribution range. Syst Biodivers 13:17-27. doi:10.1080/14772000.2014.968234

Hedenäs L, Rosborg C (2009) Pseudocalliergon is nested within Drepanocladus (Bryophyta: Amblystegiaceae). Lindbergia 33:67-74

Hedenäs L, Draper I, Milyutina I, Ignatov MS (2012) ITS and morphology tell different histories about the species of the Sciuro-hypnum reflexum complex (Brachytheciaceae, Bryophyta). Bryologist 115:153-172. doi:10.1639/0007-2745-115.1.153

Huson DH, Bryant D (2006) Application of phylogenetic networks in evolutionary studies. Molec Biol Evol 23:254-267. doi:10.1093/ molbev/msj030

Huttunen S, Bell N, Bobrova VK, Buchbender V, Buck WR, Cox CJ, Goffinet B, Hedenäs L, Ho B-C, Ignatov MS, Krug M, Kuznetsova O, Milyutina IA, Newton A, Olsson S, Pokorny L, Shaw JA, Stech M, Troitsky A, Vanderpoorten A, Quandt D (2012) Disentangling knots of rapid evolution: origin and diversification of the moss order Hypnales. J Bryol 34:187-211. doi:10.1179/1743282012Y.0000000013

Jordan WC, Courtney MW, Neigel JE (1996) Low levels of infraspecific genetic variation at a rapidly evolving chloroplast DNA locus in North American Duckweeds (Lemnaceae). Amer J Bot 83:430-439

Košnar J, Herbstová M, Kolář F, Koutecký P, Kučera J (2012) A case of intragenomic ITS variation in bryophytes: assessment of gene flow and role of plyploidy in the origin of European taxa of the Tortula muralis (Musci: Pottiaceae) complex. Taxon 61:709-720

Kreier H-P, Feldberg K, Mahr F, Bombosch A, Schmidt AR, Zhu R-L, von Konrat M, Shaw B, Shaw AJ, Heinrichs J (2010) Phylogeny of the leafy liverwort Ptilidium: cryptic speciation and shared haplotypes between the Northern and Southern Hemispheres. Molec Phylogen Evol 57:1260-1267. doi:10.1016/ j.ympev.2010.10.002

Lewis LR, Rozzi R, Goffinet B (2014) Direct long-distance dispersal shapes a New World amphitropical disjunction in the dispersallimited dung moss Tetraplodon (Bryopsida: Splachnaceae). J Biogeogr 41:2385-2395. doi:10.1111/jbi.12385

McDaniel SF, Willis HJ, Shaw AJ (2007) A linkage map reveals a complex basis for segregation distortion in an interpopulation cross in the moss Ceratodon purpureus. Genetics 176:2489-2500. doi:10.1534/genetics.107.075424

Morrison DA (2014) Is the tree of life the best metaphor, model, or heuristic for phylogenetics? Syst Biol 63:628-638. doi:10.1093/ sysbio/syu026

Morrison DA (2016) Genealogies: pedigrees and phylogenies are reticulating networks not just divergent trees. Evol Biol 43:456-473. doi:10.1007/s11692-016-9376-5

Natcheva R, Cronberg N (2004) What do we know about hybridization among bryophytes in nature? Canad J Bot 82:1687-1704. doi:10.1139/b04-139
Natcheva R, Cronberg N (2007a) Maternal transmission of cytoplasmic DNA in interspecific hybrids of peat mosses, Sphagnum (Bryophyta). J Evol Biol 20:1613-1616. doi:10.1111/j.14209101.2007.01341.x

Natcheva R, Cronberg N (2007b) Recombination and introgression of nuclear and chloroplast genomes between the peat mosses, Sphagnum capillifolium and Sphagnum quinquefarium. Molec Ecol 16:811-818. doi:10.1111/j.1365-294X.2006.03163.x

Rieseberg LH, Brouillet L (1994) Are many plant species paraphyletic? Taxon 43:21-32

Rydin C, Pedersen KR, Friis EM (2004) On the evolutionary history of Ephedra: cretaceous fossils and extant molecules. Proc Natl Acad Sci USA 101:16571-16576. doi:10.1073/pnas.0407588101

Shaw AJ (2000) Molecular phylogeography and cryptic speciation in the mosses, Mielichhoferia elongata and M. mielichhoferiana (Bryaceae). Molec Ecol 9:595-608. doi:10.1046/j.1365-294x. 2000.00907.x

Shaw AJ, Goffinet B (2000) Molecular evidence of reticulate evolution in the peatmosses (Sphagnum), including S. ehyalinum sp. nov. Bryologist 103:357-374

Shaw AJ, McDaniel SF, Werner O, Ros RM (2002) New frontiers in bryology and lichenology. Phylogeography and phylodemography. Bryologist 105:373-383. doi:10.1639/00072745(2002)105[0373:PAP]2.0.CO;2

Shaw AJ, Cox CJ, Boles SB (2005) Phylogeny, species delimitation, and recombination in Sphagnum section Acutifolia. Syst Bot 30:16-33. doi:10.1600/0363644053661823

Shaw AJ, Pokorny L, Shaw B, Ricca M, Boles S, Szövényi P (2008) Genetic structure and genealogy in the Sphagnum subsecundum complex (Sphagnaceae: Bryophyta). Molec Phylogen Evol 49:304-317. doi:10.1016/j.ympev.2008.06.009

Sonesson M (1966) On Drepanocladus trichophyllus in the Torneträsk area. Bot Not 119:379-400

Stech M (1999) Molekulare Systematik haplolepider Laubmoose (Dicranaceae, Bryopsida). PhD Thesis, Freie Universität Berlin, Berlin

Stegemann S, Keuthe M, Greiner S, Bock R (2012) Horizontal transfer of chloroplast genomes between plant species. Proc Natl Acad Sci USA 109:2434-2438. doi:10.1073/pnas.1114076109

Vanderpoorten A, Schäfer-Verwimp A, Heinrichs J, Devos N, Long DG (2010) The taxonomy of the leafy liverwort genus Leptoscyphus (Lophocoleaceae) revisited. Taxon 59:176-186

Wall DP (2002) Use of the nuclear gene glyceraldehyde 3-phosphate dehydrogenase for phylogeny reconstruction of recently diverged lineages in Mitthyridium (Musci: Calymperaceae). Molec Phylogen Evol 25:10-26. doi:10.1016/S10557903(02)00355-X

Wastegård S, Aronsson M, Hedenäs L, Johansson K, Lemdahl G, Ransed G (1996) Late Quaternary stratigraphy at Ranstad, Västergötland, southern Sweden. PACT 50:97-108

Wendel JF, Doyle JJ (1998) Phylogenetic incongruence: window into genome history and molecular evolution. In: Soltis DE, Soltis PS, Doyle JJ (eds) Molecular systematics of plants II, DNA sequencing. Chapman and Hall, New York, pp 265-296

Wyatt R, Odrzykoski IJ, Stoneburner A (2013) Isozyme evidence regarding the nature of polyploidy in the moss genus Cinclidium (Mniaceae). Bryologist 116:229-237. doi:10.1639/0007-2745116.3.229 